\title{
Sustainability at Home: An Exploratory Study on Monitoring Needs and Energy Management Actions of Solar Power Producers
}

\author{
Dounia Lahoual $^{1}$ and Myriam Fréjus ${ }^{2}$ \\ ${ }^{1}$ C3U/Paragraphe Laboratory - Université Paris 8, 2 Rue de la Liberté, Saint-Denis, France \\ dounia. lahoual@gmail.com \\ ${ }^{2}$ EDF Research \& Development, 1 Avenue Général de Gaulle, Clamart, France \\ myriam.frejus@edf.fr
}

\begin{abstract}
This exploratory study focused on the energy consumption practices of customer-producers (prosumers) in relation to their needs in monitoring energy production. Our analysis of both production monitoring activities and domestic activities in real situations revealed the motivations of these producers and demonstrated that the actions of energy management were not dependent on the status of customer-producer. The actions of energy management arose from individual and collective constructions, as well as the appropriation of electrical appliances and attractive pricing offers. These results suggest that the issue of offering incentives for energy management would benefit from greater attention to questions of appropriation, pricing, and technical devices.
\end{abstract}

Keywords: Sustainability, energy management, photovoltaic production, domestic activity, prosumers, consumption/production feedback.

\section{$1 \quad$ Introduction}

Climate change and the growing awareness of our limited resources have made energy management a key issue in today's world. For energy utilities, reducing peak demand and incorporating renewable energy sources (wind turbines, photovoltaic panels, etc.) have become priorities. Electrical systems should be operated more flexibly, and constraints due to intermittent energy production, unpredicted production and the decentralization of green energies need to be managed. To address these issues, transmission and distribution networks have favored the creation of smart grids which depend heavily on the deployment of information and communication services and technologies [3,7]. The European Grid4EU project, which includes the French NiceGrid project, was launched in 2012 in this context. The NiceGrid team is building a demonstrator of a smart solar district that incorporates both high photovoltaic energy production and storage batteries to allow each household to store energy during peak production. This project also enables the customer to balance their energy use according to their production, while taking into account the overall load on the grid. The goal of the energy utilities is to place the 
customer in the role of actor. The utilities suppose customers will become "prosumers" who actively manage their energy consumption [14, 15]. For these reasons, utility companies wish to carefully follow them (monitoring software, assistance in system installation, understanding of appropriation processes) in order to anticipate the impact of their energy production on the grids.

\subsection{The Study of Production Monitoring Activities and Consumption Practices of Energy Producers}

Underlying this project is the notion of prosumer practices and their potential impact, a field of research having much in common with the more widely investigated field of behavior modification in human-computer interactions, particularly with regard to the design and evaluation of "consumption feedback" [4, 8, 9]. Several studies provide evidence for the hypothesis that energy-producing households are more inclined to actively manage energy consumption $[17,20]$. Various means to influence consumption practices have been specifically designed, taking into account both the load on the grid and the anticipated production [13]. Moreover, studies of household energy producers suggest that they employ supervisory [10] and maintenance [6] routines. Although many studies have focused on the social acceptance of renewable energy and the emergence of local energy communities [1, 19], few have investigated prosumers, their motivations to become producers, and how they purchase solar panels. The activities of energy consumption, production monitoring, and the possible links between the two have not been sufficiently explored.

\subsection{Situating the Activities of Prosumer Energy Management in the Domestic Context}

Studies [20] have emphasized that involving householders in environmentally friendly initiatives requires not only changing intrinsic motivations, but also making much broader systemic interventions that address the circumstances surrounding the desired activity. It is well known that energy consumption practices cannot be influenced merely through the provision of information and incentives, because these practices grow out of domestic activities devoted to other objectives, such as home maintenance, meal preparation, entertainment, and so on [16]. It is therefore important to situate energy consumption in this context and to analyze the determinants of individual and collective home activities.

Our exploratory study sheds light on these issues by focusing on the following:

- The specific needs of energy producers: What information and what types of interactions are most useful to them? Do these producers carry out specific activities in managing their production? Do they have specific needs for assistance in making decisions, especially through interactive and/or informational devices?

- The relationship between energy production and consumption: Does this new status of customer-producer generate specific activities related to energy management 
or to the balance of production and consumption? Does production monitoring influence energy management?

\section{$2 \quad$ Methodology}

\subsection{Data Collection}

Study Population. Six photovoltaic (PV) energy producers were recruited for this exploratory study (Table 1). The homes were equipped with solar panels and electric heating, and the households were at different stages in appropriating the production management system, which allowed us to carry out a diachronic analysis.

Table 1. Characteristics of the participants and summary of collected data

\begin{tabular}{|c|c|c|c|c|c|c|}
\hline $\begin{array}{l}\text { Age of } \\
\text { participants }\end{array}$ & $\begin{array}{l}\text { Producers } \\
\text { since }\end{array}$ & $\begin{array}{l}\text { Profession } \\
\text { of solar } \\
\text { power } \\
\text { producers }\end{array}$ & $\begin{array}{l}\text { Family } \\
\text { composition }\end{array}$ & $\begin{array}{l}\text { Exploratory } \\
\text { interviews }\end{array}$ & $\begin{array}{l}\text { Collective } \\
\text { self- } \\
\text { confrontation } \\
\text { interviews }\end{array}$ & $\begin{array}{l}\text { Video } \\
\text { recording }\end{array}$ \\
\hline $\begin{array}{l}\text { (1) Mr L. (45 } \\
\text { years old) }\end{array}$ & 2 years & $\begin{array}{l}\text { Executive } \\
\text { officer in } \\
\text { tourism }\end{array}$ & $\begin{array}{l}\text { Married } \\
\text { with one } \\
\text { young child } \\
\text { ( } 3 \text { people) }\end{array}$ & $1 \mathrm{~h} 23$ & $2 \mathrm{~h} 44$ & $8 \mathrm{~h}$ \\
\hline $\begin{array}{l}\text { (2) Mrs N. } \\
\text { (42 years } \\
\text { old) }\end{array}$ & 6 months & $\begin{array}{l}\text { Household } \\
\text { electrical } \\
\text { saleswoman }\end{array}$ & $\begin{array}{l}\text { Divorced } \\
\text { with two } \\
\text { teenage } \\
\text { daughters } \\
\text { (3 people) }\end{array}$ & $1 \mathrm{~h} 53$ & $1 \mathrm{~h} 05$ & $8 \mathrm{~h}$ \\
\hline $\begin{array}{l}\text { (3) Mr F. (57 } \\
\text { years old) }\end{array}$ & $\begin{array}{l}1 \text { year \& } 5 \\
\text { months }\end{array}$ & $\begin{array}{l}\text { Retired } \\
\text { (former } \\
\text { train driver) }\end{array}$ & $\begin{array}{l}\text { Couple } \\
\text { (2 people) }\end{array}$ & $2 \mathrm{~h} 43$ & $2 \mathrm{~h} 14$ & $8 \mathrm{~h}$ \\
\hline $\begin{array}{l}\text { (4) Mr P. (61 } \\
\text { years old) }\end{array}$ & $\begin{array}{l}1 \text { year \& } 7 \\
\text { months }\end{array}$ & $\begin{array}{l}\text { Retired } \\
\text { (former } \\
\text { computer } \\
\text { engineer) }\end{array}$ & $\begin{array}{l}\text { Couple with } \\
\text { two teenage } \\
\text { children } \\
\text { (4 people) }\end{array}$ & $1 \mathrm{~h} 22$ & I & I \\
\hline $\begin{array}{l}\text { (5) Mr Ca. } \\
\text { (50 years } \\
\text { old) }\end{array}$ & $\begin{array}{l}2 \text { years \& } \\
6 \text { months }\end{array}$ & Teacher & $\begin{array}{l}\text { Couple with } \\
\text { three } \\
\text { children } \\
\text { ( } 5 \text { people) }\end{array}$ & $38 \mathrm{~min}$ & I & I \\
\hline $\begin{array}{l}\text { (6) Mr Co. } \\
\text { (52 years } \\
\text { old) }\end{array}$ & 3 years & $\begin{array}{l}\text { Inactive } \\
\text { (previously } \\
\text { wine- } \\
\text { grower) }\end{array}$ & $\begin{array}{l}\text { Couple with } \\
\text { one child } \\
\text { (3 people) }\end{array}$ & $15 \mathrm{~min}$ & I & I \\
\hline
\end{tabular}

Interviews. We first carried out exploratory telephone interviews with three of the producers $(4,5$, and 6 in Table 1$)$ in order to determine their motivations to become energy producers, their personal projects, their patterns of energy consumption, and their energy management actions. These elements aimed to complete the bibliographical research in order to refine the methodology of the study and the recruitment criteria of participants. 
Collecting the Audiovisual and Written Data on Domestic Activities. To reconstruct the situated dynamics of domestic activity, our study was conducted within the theoretical and methodological framework of the Course-of-Action research program. The Course-of-Action methodology allows grasping the meaning each householder gives to his or her own activity $[11,18]$. We filmed three of the households $(1,2$, and 3 in Table 1) in order to gain insight into their individual and collective activities (the long duration of recruitment limited us to three households). The recording set-up was as follows: unobtrusive mini-cameras with a $120^{\circ}$ view angle and equipped with microphones were programmed to begin recording in our absence. Several switches allowed the households to interrupt the sound and video recording if needed. The time and the place for recording were scheduled after discussion and validation by the households (formalized by the signature of an agreement). Several rooms with high activity levels were chosen for recording: the kitchen, the living room and a main hallway where the residents mainly circulated. For each room, we scheduled continuous recordings of two hours in four moments in the week in order to collect various domestic activities (with the household's agreement). In addition, every day the residents used a notebook developed for this study to provide requested information on the use of a range of electrical appliances. Both notebooks and video recordings were used in the self-confrontation interviews in order to grasp the meaning they attributed to their activities in situation (viewpoints, motivations and goals). To achieve this, we selected recording and notebook sections on the basis of clearly defined criteria: the chronological aspect and the unexpected nature of domestic activities, the presence of energy management actions and activities mediated by electrical devices. The households were compensated for participating with discount vouchers.

\subsection{Data Analysis}

Data Transcription. The video recordings of the home activities were transcribed using the multi-score method [5]. This method allowed us to summarize the inhabitants' actions from their individual viewpoints and the chronological use of electrical appliances in relation to the space they occupied (see Table 2).

Constructing Shortened Stories. We constructed shortened stories, which were chronological presentations of the meaningful units of activity in which the inhabitants were engaged [12]. These narratives were constructed from the multi-score transcriptions.

Analysis. The analysis sought to model production monitoring activities and the instantiation of control activities in the domestic courses of action. Concerns and the resulting generation of action from each individual's point of view were described and compared, as were items of knowledge mobilized for the action and any meaningful elements that were used to act. 


\section{$3 \quad$ Results}

\subsection{Identifying Activities Linked to Monitoring PV Energy Production}

Motivations of the Customer-Producers. The PV producers had two main motivations. The first was financial and, in this sense, the financial aid given to install the panels and the guarantee that all generated energy would be purchased by the supplier were a determinant. Energy self-sufficiency over the long term was also an important consideration with regard to an eventual end to the supplier's guaranteed buy-back price and the progressive rise in electricity costs.

Producers Specific Activities. After the system was installed, several activities related to production monitoring were noted. All the producers verified that the system was functioning correctly, that enough energy was being produced, and that technical defects or breakdowns had indeed not occurred. These activities were carried out with the support of several devices: an inverter (with light or sound displays representing the functioning of the inverter) used by three households (1,2, and 3 in Table 1), a production meter ( $\mathrm{kWh}$ on the display) used by only one producer (6), and monitoring software (the default setting being the daily production graphics) used by two producers (4 and 5). In addition to ensuring the proper functioning of the PV system, three participants (3,4 and 5) performed another activity, though this was less frequent: tracking the energetic and financial profitability of the system. In the first case, two participants ( 3 and 4 ) with varying frequency, monitored the system efficiency by taking readings from the inverter in $\mathrm{kWh}$ of production and transferring this data to Excel spreadsheets for personalized and ongoing tracking (e.g., converting to Euros, comparing energy produced to consumed, etc.). Tracking the financial profitability (done by producer 3 ) involved the same activities but the goal was slightly different: trying to determine the point in time at which the financial gains from selling energy would be greater than the financial outlay for the installation, thus ensuring a regular income. In addition to these monitoring activities, participation in online discussion forums was a veritable resource for support and problem-solving during the installation phase. Three producers were involved in forums $(4,5$ and 6$)$. Two distinct profiles of these energy producers nevertheless emerged from our analysis: three households (1,2 and 6) carried out light, routine monitoring mostly to simply ensure proper technical functioning and the other half $(3,4$ and 5) who were much more involved. These latter monitored the system much more closely and systematically and clearly sought profitability and/or energy self-sufficiency. They were also much more invested in participating in the specialized internet forums.

\subsection{Domestic Activities and Energy Management}

Actions of Energy Management. The analysis of the domestic activities revealed a repertory of actions for energy control. These actions arose sporadically in the midst of the domestic activity and usually indicated a concern about energy use during the course of the activity (reducing energy costs, avoiding waste, taking advantage of an 
energy resource already in use, etc.). Several forms of energy control were identified in the data: shifts in the times of use, grouping energy uses together, finding shortcuts, voluntarily avoiding energy use, turning appliances off, insulating, and making targeted purchases (certain of which were also noted by Pierce and al. [9]). These actions were fully incorporated into the domestic activities, such as systematically turning off an electrical burner before the food was completely heated in order to take advantage of inertia (household 1 in Table 1), turning lights off on leaving a room (all the participants), letting natural light in rather than turning on electrical lights $(1,2$ and 3 in Table 1), etc. These gestures were both automatic and easy to do. They did not guide any of the domestic activities but rather were performed sporadically. These control actions were also built up over time. In some cases, incentives prompted these actions. For example, the option and lower cost of running appliances at off-peak times encouraged a shift in the time of using washing machines and dishwashers $(1,3$, 4 and 5). In other cases, personal experience prompted change, as for the homemaker who had lived in Cuba (1), where energy constraints are high. She had noted a sharp rise in her electrical bill when she ironed clothes and thus had developed the habit of grouping together her ironing into single sessions and then spacing the ironing sessions out. This person displayed a culture built up around the links between energy usage and energy cost and she thus also grouped stovetop cooking around a single burner: she had determined that turning off an electric burner and then turning it on again was more costly. These control actions were shared by all household members and could in some cases be described as co-realized. For example, the couple (1) coordinated doing the laundry, with the woman preparing a laundry load during the day and the man starting the washing machine in the evening during the off-peak period. All in all, we observed a plurality of uses, including three (shifting, grouping and shortening) which illustrate the appropriation of electrical devices. The analysis thus indicated that, to encourage home energy management, household members need to fully appropriate their electrical appliances, which means that they are free to use them as they see fit with regard to their home activities, external parameters (weather, climate), and the comfort level they are seeking. Indeed, the observed control actions revealed that households do not necessarily use the electrical appliances as initially envisioned by the designers. It also implies that they have access to the services that support their actions (pricing, management systems). The actions of energy management should not interfere with any of their normal home activities.

Energy Producers: Customers as Actors in Their Own Consumption? The quantity of generated solar power is not a criterion to guide consumption because, first of all, in the households we observed consumption was on average about ten times greater than the PV production. Moreover, we observed that the actions of energy management resulted from the appropriation of electrical appliances and attractive price offers, which were independent of the status of producer. These actions reflected individual and collective constructions of appropriation and could surely be carried out by all customers, given favorable conditions and the means to integrate them into more general domestic practices. We thus confirm that the actions of energy management are not linked to the status of customer-producer: you become a producer 
because you are already an actor - that is, because you are already involved in energy management - and not the reverse. The shift to producer is a step in an overall project of energy control, where the development of actions to manage energy consumption and the ability to use available resources are prerequisites.

\section{Conclusion and Perspectives}

This exploratory study provides two orientations for the design and development of future research: the design of systems to visualize and monitor energy consumption in relation to production and the further investigation of how the actions of energy management develop. Within the framework of monitoring design, this study indicates the types of information that should be displayed by inverters, the functions that are most useful in monitoring software, and the types of energy information that should be available inside the home. Specifically, we have determined that monitoring tools should target long time scales linked to the expectation of profitability and daily and monthly analyses. The monitoring system should not offer only information on real-time data. In fact, to encourage energy management, it is crucial to facilitate householders' appropriation of technical devices, electrical appliances and advantageous pricing offers that orient the organization of domestic courses of actions. Domestic activities could be assisted by automatic systems that take over for the residents (starting the washing machine during off-peak hours). However, any actions of automatic energy management need to be transparent to the household members and should not cause any disruption of household routines. The question of how to coordinate automatic control systems with ongoing home activities (distribution of automatic operations, visibility and easy recourse to manual control) is thus clearly posed, pointing back to a fundamental issue of human-computer interaction design. Last, this study suggests that the debate on energy management will be enriched by a shift of emphasis toward questions of appropriation, which we believe are essential [2]: we need to think about designing future situations of energy management in terms of those situations that are appropriable. Other studies are needed for us to instantiate this objective in the design and evaluation of the neighborhood solar project we are currently engaged in. Our future studies will be longitudinal studies in order to understand how individual and collective behaviors and energy management practices are built before and after the insertion of production systems.

\section{References}

1. Alvial-Palavicino, C., Garrido-Echeverría, N., Jiménez-Estévez, G., Reyes, L., PalmaBehnke, R.: A methodology for community engagement in the introduction of renewable based smart microgrid. In: 2011 International Energy Initiative. Elsevier Inc. (2011)

2. Dix, A.: Designing for appropriation. In: Proc. HCI 2007, pp. 27-30 (2007) 
3. Fan, Z., Kalogridis, G., Efthymiou, C., Sooriyabandara, M., Serizawa, M., McGeehan, J.: The New Frontier of Communications Research: Smart Grid and Smart Metering. In: Proceedings of the 1st International Conference on Energy-Efficient Computing and Networking (2010)

4. Froehlich, J., Findlater, L., Landay, J.: The design of eco-feedback technology. In: Proc. CHI 2010 (2010)

5. Guibourdenche, J., Vacherand-Revel, J., Grosjean, M., Fréjus, M., Haradji, Y.: Transcribing the activity of a distributed family. In: Proc. CSCW, pp. 637-640. ACM DL, China (2011)

6. Juntunen, J.: Domestication of small-scale renewable energy systems - A case study of air heat pumps, residential micro wind stations and solar thermal collectors in Finland. In: EcoDesign 2011 (2011)

7. Lampropoulos, I., Vanalme, G., Kling, W.: A methodology for modeling the behavior of electricity prosumers within the smart grid. In: Proc. of the 2010 IEEE PES Conference ISGT Europe (2010)

8. Pierce, J., Fan, C., Lomas, D., Marcu, G., Paulos: Some consideration on the (in)effectiveness of residential energy feedback systems. In: DIS 2010 (2010)

9. Pierce, J., Schiano, D., Paulos, E.: Home, Habits, and Energy: Examining Domestic Interactions and Energy Consumption. In: Proc. CHI 2010 (2010)

10. Pierce, J., Paulos, E.: The Local Energy Indicator: Designing for Wind and Solar Energy Systems in the Home. In: Proc. DIS 2012 (2012)

11. Pinsky, L., Pavard, B.: What Does Real Work Analysis Tell Us about System Design? In: van der Veer, G.C., Green, T.R.G., Tauber, M.J., Gorny, P. (eds.) Readings on Cognitive Ergonomics, Mind and Computers. LNCS, vol. 178, pp. 248-259. Springer, Heidelberg (1984)

12. Poizat, G., Fréjus, M., Haradji, Y.: Analysis of collective activity in domestic settings for the design ubiquitous technologies. In: Proc. ECCE. ACM DL (2009)

13. Schrammel, J., Gerdenitsch, C., Weiss, A., Kluckner, P.M., Tscheligi, M.: FORE-Watch The clock that tells you when to use: Persuading users to align their energy consumption with green power availability. In: Keyson, D.V., et al. (eds.) AmI 2011. LNCS, vol. 7040, pp. 157-166. Springer, Heidelberg (2011)

14. Shandurkova, I., Bremdal, B., Bacher, R., Ottesen, S., Nilsen, A.: A prosumer oriented energy market: developments and future outlooks for smart grid energy markets. Improsume Publications Series (2012)

15. Shuen, A.: Web 2.0 A Strategy Guide (2008), http: / /www.scribd.com/doc/15490958/Web-20-A-StrategyGuide-by-OReilly-Media (retrieved June 14, 2010)

16. Stern, P.C.: What Psychology knows about energy conservation. American Psychologist 47(10), 1224-1232 (1992)

17. Strengers, Y.: Designing eco-feedback systems for everyday life. In: Proc. CHI 2011 (2011)

18. Theureau, J.: Course of Action Analysis \& Course of Action Centered Design. In: Hollnagel, E. (ed.) Handbook of Cognitive Task Design, pp. 55-81. Lawrence Erlbaum Ass., Mahwah (2003)

19. Walker, G., Devine-Wright, P.: Community renewable energy: What should it mean? Energy Policy 36, 497-500 (2008)

20. Woodruff, A., Hasbrouck, J., Augustin, S.: A Bright Green Perspective on Sustainable Choices. In: Proc. CHI 2008, Florence, Italy, pp. 313-322 (April 2008) 